\title{
Питання зовнішнього контролю якості лабораторних досліджень на сифіліс у лікувальних закладах України
}

\author{
В.В. Кутова, Я.Ф. Кутасевич, О.М. Білоконь, Т.В. Дегтяр, І.Н. Нікітенко, Ю.В. Щербакова \\ ДУ «Інститут дерматології та венерології НАМН України»
}

\begin{abstract}
Резюме
Мета роботи - виявлення систематичних івипадкових помилок при постановці контрольованих методів ідосягнення порівнянних результатів, які отримуються лабораторіями, що беруть участь у зовнішньому контролі якості лабораторних досліджень на сифіліс.

Матеріали і методи. У заходах проведення зовнішнього контролю якості серологічної діагностики сифілісу взяли участь лабораторії трьох рівнів: клініко-діагностичні лабораторії (КДЛ) лікувально-профілактичних закладів науково-дослідних інститутів НАМН України, серологічні відділи в складі КДЛ дерматовенерологічного профілю ОШВД, централізовані серологічні лабораторії міських шкірно-венерологічних диспансерів (МШВД).
\end{abstract}

Результати. Оцінена якість проведення серологічних досліджень на сифіліс в 21 КДЛ (серологічних відділах) за методами: РМП ( реакція мікропреципітації), РПР (реакція швидких плазмових реагінів), ІХГ (імунохроматографія), РПГА (реакція пасивної гемаглютинації), ІФА (імуноферментний аналіз), РІФ абс (реакція імунофлуоресценції з абсорбцією) у трьох контрольних зразках сироватки за формальними й істотними ознаками. Найбільш значущі відмінності результатів були виявлені при дослідженні контрольних зразків сироватки з низьким вмістом антитіл та що не містять антитіла до збудника сифілісу в нетрепонемному тесті РМП і трепонемному тесті РІФ абс

Висновки. Проведені дослідження показали високу ефективність практичного застосування розробленої системи зовнішнього контролю якості лабораторних методів діагностики сифілісу.

Ключові слова: сифіліс, зовнішній контроль якості, серологічні дослідження.

DOI: 10.33743/2308-1066-2021-2-15-19

\section{Вступ}

Останніми роками неухильно зростає інтерес до методів діагностики захворювань, що передаються статевим шляхом, зокрема до діагностики сифілісу. Це пов'язано з величезними соціальними і економічними збитками, які приносять зазначені інфекції. Ще в недавньому минулому лабораторна діагностика таких інфекцій, як сифіліс, здійснювалася, як правило, тільки в спеціалізованих дерматовенерологічних закладах $[9,11]$.

Широке впровадження сучасних методів діагностики дало змогу перенести основну масу досліджень на рівень лабораторій практичної охорони здоров’я. 3 одного боку, це зробило діагностику доступнішою, а з іншого породило цілу низку проблем, пов'язаних із забезпеченням необхідної якості досліджень $[6,7,10]$.

Широкий арсенал засобів, розроблений дотепер для діагностики сифілісу, ставить працівників практичної охорони здоров'я перед необхідністю вибору методу, оптимального для застосування в умовах конкретного лікувального закладу. При цьому на перший план висуваються проблеми технічного і економічного характеру, а питання організації зовнішнього і внутрішньолабораторного контролю якості дослідження відходять на другий план [3, 4].
Систематична оцінка якості виконуваних лабораторних досліджень у даний час визнана невід'ємною складовою діагностичного процесу. Забезпечення якості досліджень у клінічній лабораторії має на увазі здійснення широкого спектра процедур, починаючи 3 контролю якості обладнання та реагентів і закінчуючи перевіркою клінічної значущості результатів аналізів $[2,8]$.

Обов'язковою ланкою в забезпеченні якості лабораторних досліджень є внутрішньолабораторний контроль. В умовах серологічної лабораторії він охоплює контроль якості реагентів і оцінку достовірності результату шляхом використання завідомо позитивних і негативних контролів [5].

На жаль, слід визнати, що далеко не всі методи, що нині впроваджуються в широку лабораторну практику, забезпечують можливість надійного внутрішньолабораторного та зовнішнього контролю якості діагностичних досліджень. Важливо відмітити, що цільної системи або програми із зовнішнього оцінювання якості лабораторних досліджень на сифіліс не має жодна країна світу, у тому числі Україна [12].

Контроль якості лабораторних досліджень є одним із методів удосконалення діяльності діагностичних лабораторій. Результати серологічних досліджень 


\section{КЛІНІЧНІ СПОСТЕРЕЖЕННЯ}

на сифіліс залежать від безлічі чинників, довільна зміна будь-якого з них може призвести до необ'єктивних і спотворених результатів дослідження.

Зовнішній контроль якості (ЗКЯ) - це порівняльний контроль якості результатів лабораторних досліджень, отриманих у низці лабораторій. Він дає змогу виявляти помилкові результати дослідження, що призводять до гіпо- або гіпердіагностики захворювань, оцінити професійну підготовку персоналу лабораторій, стандартизувати і уніфікувати методи досліджень і своєчасно здійснювати заходи з поліпшення якості роботи лабораторій [1].

Мета роботи - виявлення систематичних і випадкових помилок при постановці контрольованих методів і досягнення порівнянних результатів, які отримуються лабораторіями, що беруть участь у ЗКЯ лабораторних досліджень на сифіліс.

\section{Матеріали і методи дослідження}

У заходах із ЗКЯ серологічної діагностики сифілісу взяли участь лабораторії трьох рівнів: клініко-діагностичні лабораторії (КДЛ) лікувально-профілактичних закладів, науково-дослідних інститутів НАМН України, серологічні відділи в складі Кдл обласних шкірно-венерологічних диспансерів (ОШВД), централізовані серологічні лабораторії міських шкірно-венерологічних диспансерів (МШВД). Серед лабораторійучасників циклів ЗКЯ були представники 20 областей України.

У 2018-2020 рр. у заходах із ЗКЯ серологічної діагностики сифілісу взяли участь також лабораторії непрофільних закладів: станції переливання крові, центральних, міських і районних лікарень, військового госпіталю, поліклінічних відділень першого рівня надання допомоги населенню. Серологічні дослідження здійснювали згідно з методичними вказівками, викладеними в Наказах МОЗ України [4-6, 9].

\section{Результати досліджень}

У рамках договорів про науково-практичне співробітництво в лабораторії, які контролювались, розсилали контрольні матеріали - зразки сироватки крові. Контроль здійснювали відповідно до Програми згідно з графіком. Одна зі сторін-учасниць Програми в особі референс-лабораторії із ЗКЯ серологічних досліджень на сифіліс НАМН України ДУ «ІДВ НАМН України» надавала контрольний матеріал іншим сторонам-учасникам ЗКЯ. Визначення показників у контрольному матеріалі кожна зі сторін здійснювала самостійно із застосуванням комерційних тест-систем і реагентів, зареєстрованих (сертифікованих) в Україні.

Контрольні матеріали (КМ) у зашифрованому вигляді надсилали поштою в лабораторії, що брали участь у виконанні заходів Програми. До числа контрольованих тестів були віднесені наступні методи: нетрепонемні тести (НТТ): реакція мікропреципітації (РМП модифікація ВДРЛ); реакція швидких плазмових реагінів (РПР) і трепонемні тести (ТТ): імунохроматографічний (IXГ) тест, реакція пасивної гемаглютинації (РПГА), реакція імунофлуоресценції з абсорбцією (РІФ абс), метод імуноферментного аналізу (IФА) 3 визначенням трепонемоспецифічних імуноглобулінів класів IgG, IgM (окремо або сумарно; не менш ніж у трьох реакціях).
При виконанні досліджень аналіз контрольних проб проводили в ході звичайної роботи лабораторії, проводився тим самим персоналом, який виконує ці дослідження повсякденно. На всіх етапах ЗКЯ проводилось надання консультативно-методичної допомоги. ЗКЯ здійснювався в декілька етапів: отримання контрольних матеріалів для тестування; проведення досліджень і отримання результатів; систематизація результатів дослідження.

Результати, отримані для кожного окремого контрольного зразка, заносили в протокол, який надсилався й аналізувався в референс-лабораторії із ЗКЯ лабораторних досліджень на сифіліс НАМН України ДУ «ДВ НАМН України».

Результат тестування оцінювали за формальними і неформальними (суттєвими) ознаками. Результат ЗКЯ вважали незадовільним за формальними ознаками, якщо дослідження здійснювалося у невстановлені терміни (довше 10 днів з моменту отримання КМ в лабораторії) і якщо дослідження КМ здійснювалося менш ніж у трьох серологічних реакціях із числа регламентованих для проведення ЗКЯ: РМП, РПР, ІХГ, IФА, РПГА, РІФ аб. Результат вважали незадовільним за суттєвими (неформальними) ознаками у випадку неспівпадіння результатів дослідження КМ у контролюючій лабораторії і тій, що перевіряється.

За результатами ЗКЯ встановлено, що лабораторії застосовують різні комбінації НТТ і ТТ для підтвердження або виключення діагнозу сифіліс. Так, 19,0\% лабораторій використовують у своїх дослідженнях 1 НТТ і 4 TT, 28,5\% лабораторій - 1 НТT та 3 TT, 42,8\% лабораторій - 1 HTT і 2 TT і 9,5\% лабораторій - 1 НTT і 1 TТ (рис. 1).

Відсоток правильних результатів при постановці РМП серед найбільш застосовуваних тестів, які використовують для визначення реагінових антитіл під час скринінгової діагностики сифілісу, становив 90,5\%, відсоток незадовільних результатів - 9,5\%. При якісній постановці РМП загалом спостерігали співпадіння результатів (позитивно-негативний). Але в низці випадків мало місце розходження в напівкількісному обліку результатів, яке виражається в умовних одиницях.

Найбільшу кількість (55\%) незадовільних результатів НТТ у контрольованих лабораторіях було отримано

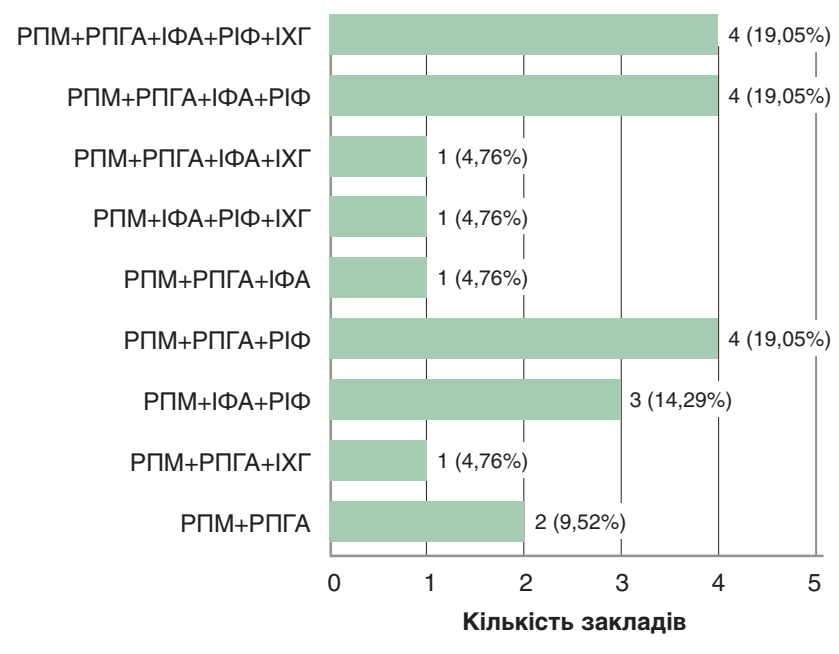

Рис. 1. Застосування комбінацій серологічних методів діагностики в КДЛ дерматовенерологічних закладів України (n=21) 


\section{КЛІНІЧНІ СПОСТЕРЕЖЕННЯ}

при дослідженні сироватки, яка мала реагінові антитіла в низькій концентрації, при цьому результати з меншим значенням титру у порівнянні з атестованими характеристиками сироватки становила 45\% помилок, з більшим значенням титру - 35\% помилок. Значна частина помилкових результатів у РМП (25\%) була пов'язана 3 «гіпердіагностикою» і отриманням хибнопозитивних результатів з КМ, що не містять антитіла до Treponema pallidum. Розбіжність в оцінці титрів реагінових антитіл у КМ з високим титром антитіл до T. pallidum не спостерігалася.

Кількість лабораторій, що виконують РПР, по Україні становила 15\%. Ця реакція в 100\% давала правильні відповіді в якісній постановці. При подальшій напівкількісній реакції РПР титри антитіл були значно нижчими, ніж за методом РМП. Тест РПР, за даними лабораторій, був менш трудомістким, ефективнішим і об'єктивнішим у порівнянні з методам РМП в якісній постановці, що дає змогу використовувати його у складі нового комплексу серологічних досліджень на сифіліс на первинній ланці обстеження населення.

Аналіз частоти використання наборів реагентів для постановки НТТ (РМП) показав, що найчастіше для цієї мети застосовували набори: ПрАТ «НВК «ДІАПРОФМЕД», ТОВ «Діагностичні системи України», ПАТ «Фармстандарт-Біолік», ТОВ «Лабораторія Гранум». Найменш успішним у використанні (з інформації анкетних даних лабораторій) був набір реагентів ТОВ «Лабораторія Гранум».

Таким чином, за даними циклу ЗКЯ 2018-2020 pр., відсоток правильних відповідей при постановці РМП найбільш часто вживаного тесту для визначення реагінових антитіл при серодіагностиці сифілісу - становив 90,5\%, відсоток незадовільних результатів - 9,5\% (рис. 2).

Отримання такого високого відсотка незадовільних результатів свідчить про істотні проблеми якості скринінгової серологічної діагностики сифілісу, пов’язані з використанням у лабораторіях РМП, що призводять до гіпердіагностики або невиявлення хворих із сифілітичною інфекцією. Ці проблеми можуть бути пов'язані як $з$ помилками, що допускаються на преаналітичній, аналітичній і постаналітичній стадіях лабораторної діагностики, так і з недостатньо високою якістю наборів реагентів, що надходять на ринок України.

Заходи щодо виправлення ситуації, що склалася, і покращення якості діагностики сифілісу із застосуванням РМП мають бути спрямовані на створення в лікувально-діагностичних установах системи менеджменту якості, що забезпечує оптимізацію взаємодії співробітників лабораторій і лікувальних підрозділів, розвиток внутрішньолабораторного контролю якості, а також закупівлі діагностичних тестів, які відповідають стандартам якості.

Одним із заходів підвищення якості виконання НТT може також бути проведений на регулярній основі ЗКЯ лабораторної діагностики сифілісу із застосуванням розширеного спектра КМ і постійним ускладненням контрольних завдань, а також впровадження в лабораторну практику РПР.

Не спостерігалось розходжень при постановці методу ІФА, в якому мінімізовано суб’єктивний фактор оцінки результатів. Дослідження матеріалів за допомогою ІФА було здійснено в більшості серологічних

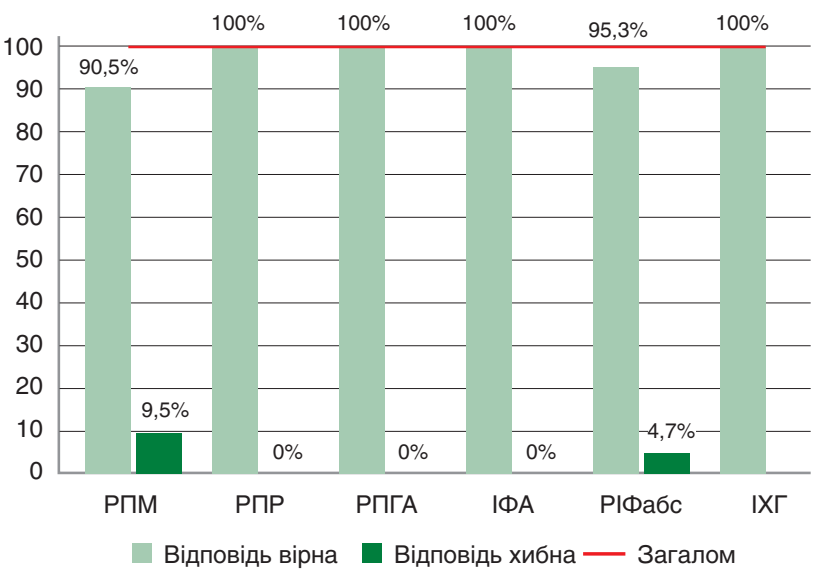

Рис. 2. Результати ЗКя при дослідженні КМ у серологічних дослідженнях

лабораторій. Але слід відмітити, що в 38,0\% дерматовенерологічних закладів постановка ІФА не проводиться через відсутність імуноферментного аналізатора або діагностичних тест-систем. Вказаний метод наразі найбільш використовується як скринінговий і підтверджуючий ТТ для діагностики сифілісу, оскільки більшість етапів його проведення автоматизовані, методика стандартизована і для виконання дослідження є великий вибір тест-наборів, сертифікованих в Україні (див. рисунок 2).

Одним зі стандартизованих тестів для виявлення антитіл до T. pallidum є РПГА, її виконання не потребує спеціального вимірювального обладнання. Кількість незадовільних результатів при постановці РПГА загалом по країні не зареєстровано (див. рисунок 2).

При оцінці якості РІФ абс («золотого стандарту») у серологічних лабораторіях дерматовенерологічних закладів країни під час проведення 3КЯ в 4,7\% були отримані результати, які не відповідали критеріям якості досліджень (див. рисунок 2). Незадовільні результати РІФ абс охоплювали хибнопозитивні результати, отримані 3 KM, які не мали антитіл до T. pallidum, i peзультати зі слабшою позитивністю (оцінювали в умовних плюсах) порівняно з атестованими характеристиками в зразках, що містили антитіла до T. pallidum у низьких концентраціях. Слід відмітити, що діагностичні набори для постановки даного тесту з 2021 р. в Україні відсутні.

Таким чином, як показали результати ЗКЯ, при дослідженні КМ у ТТ було допущено значно менше число помилок (в IXГ - 0\%, РІФ абс $-4,7 \%$, РПГА - 0\%, IФA - 0\%), ніж у НTT (РМП -9,5\%). Ця обставина свідчить про необхідність широкого використання зазначених методів діагностики (особливо ІХГ і РПГА) як для скринінгу, так і для підтвердження наявності сифілітичної інфекції (див. рисунок 2).

Розгортання масової діагностики сифілісу в практичних закладах охорони здоров’я і в приватних лабораторіях не завжди підкріплюється адекватними заходами, спрямованими на забезпечення контролю якості досліджень. Навряд чи доцільно впровадження методів, при використанні яких постійний контроль якості досліджень неможливий.

\section{Висновки}

3 метою підвищення якості діагностики сифілісу, а також виявлення системних помилок лабораторних 


\title{
КЛІНІЧНІ СПОСТЕРЕЖЕННЯ
}

методів і підтримання єдності вимірювань на території всієї країни необхідно провести заходи щодо:

- створення лабораторних центрів в обласних, міських дерматовенерологічних закладах та на республіканському рівні, які здійснюватимуть ЗКЯ лабораторних досліджень на сифіліс як у медичних закладах МОЗ України, так і в приватних лабораторіях;

- створення системи зовнішнього і внутрішньолабораторного контролю якості в лікувально-діагностичних

\section{Література}

1. Кутова В.В., Білоконь О.М., Дегтяр Т.В. Зовнішній контроль якості серологічних досліджень на сифіліс. Матеріали науково-практичної конференції з міжнародною участю «Інфекційні хвороби сучасності: етіологія, епідеміологія, діагностика, лікування, профілактика, біологічна безпека». Дерматологія та венерологія. 2020. № 3(77). С. 154-155.

2. Кутова В.В., Волкославська В.М., Білоконь О.М. Характеристика стану, ресурсів лабораторій дерматовенерологічних закладів, які виконують комплекс стандартних серологічних реакцій на сифіліс. Дерматологія та венерологія. 2017. № 3(77). С. 85-91.

3. Наказ МОЗ України № 286 від 07.06.2004р. «Про удосконалення дерматовенеролочної допомоги населенню України ..

4. Наказ МОЗ України № 997 від 22.11.2013 р. Про затвердження Методичних рекомендацій «Сучасні підходи до лабораторної діагностики сифілісу».

5. Наказ МОЗ України № 204 від 29.12.1992 р. «Про організацію лабораторної діагностики сифілісу в Україні» (зі змінами, внесеними згідно з Наказом МОЗ № 21 від 3.01.97) 6. Практические аспекты серологической диагностики сифилиса на современном этапе / Я.Ф. Кутасевич, В.В. Кутовая, О.Н. Белоконь [и др.] Дерматологія та венерологія. 2020 № 1(87). C. 39-43. DOI: 10.33743/2308-1066-2020-1-39-43

7. Роль нетрепонемних лабораторних методів дослідження у діагностиці сифілітичної інфекції / В.В. Кутова, О.М. Білоконь, І.М. Нікітенко [та ін.]. Дерматологія та венерологія.

8. Ротанов С.В. Мероприятия внешнего контроля качества серологических исследо-
(2). ваний, направленных на серодиагностику сифилиса. Вестник дерматологии. 2008. № 4. C. $9-16$.

9. Сифилис: современное состояние проблемы / Г.М. Бондаренко, С.В. Унучко и.Н. Никитенко [и др.] Дерматологія та венерологія. 2018. № 1(79). С. 8-12

10. Удосконалення лабораторної діагностики сифілісу в Україні. Методичні рекоменда10. Удосконалення лабораторної діагностики сифілісу в Україні.
ції / Я.Ф. Кутасевич, О.І. Літус, В.В. Кутова [та ін.]. Київ, 2019. 28 с.

11. 2014 European guideline on the management of syphilis / M. Janier, V. Hegyi, N. Dupin [et al.]. J. Eur. Acad. Dermatol. Venereol. 2014. N20. P. 300-9. DOI: 10.1111/jdv.12734

12. Young H. Guidelines for serological testing for syphilis. Sex Transm. Infect. 2000. № 76 P. 403-405. DOI: $10.1136 /$ sti.76.5.403 закладах охорони здоров’я, які здійснюють дослідження з метою діагностики сифілісу;

- підвищення чутливості і специфічності промислових наборів реагентів для серологічних досліджень на сифіліс, особливо для скринінгових НТТ;

- розробки розширених панелей КМ, що дають змогу ускладнювати контрольні завдання в циклах ЗКЯ і ставити перед лабораторіями нові завдання, спрямовані на підвищення якості серологічних досліджень на сифіліс.

\section{References}

1. Kutova W, Bilokon OM, Dehtiar TV. Zovnishnii kontrol' yakosti serolohichnykh doslidzhen' na syfilis. Materialy naukovo-praktychnoi konferentsii z mizhnarodnoiu uchastiu «Infektsiini khvoroby suchasnosti: etiolohiia, epidemiolohiia, diahnostyka, likuvannia, profilaktyka, biolohichna bezpeka [External quality control of serological tests for syphilis. Proceedings of the scientificpractical conference with international participation «Infectious diseases of today: etiology, epidemiology, diagnosis, treatment, prevention, biological safety"]. Dermatolohiya ta venerolohiya. 2020;3(77):154-5. [in Ukr.]

2. Kutova VV, Volkoslavs'ka VM, Bilokon' OM. Harakteristika stanu, resursiv laboratorij dermatovenerologichnih zakladiv, yaki vikonuyut' kompleks standartnih serologichnih reakcij na sifilis [Characteristics of the status, resources of laboratories of dermatological venereological institutions that perform a complex of standard serological reactions to syphilis]. Dermatologiya venerologiya. 2017;3(77):85-91. [in Ukr.]

3. Nakaz MOZ Ukraini № 286 vid 07.06.2004 «Pro udoskonalennya dermato-venerologichnoï dopome 2004 "On impro
[in Ukr.] in Ukr.

4. Nakaz MOZ Ukraïni № 997 vid 22.11.2013. Metodichni rekomendaciï «Suchasni pidhodi do laboratornoï diagnostiki sifilisu» [Order ofthe Ministry of Health ofUkraine No. 997 dated November 22, 2013. of Syphilis"]. [in Ukr.]

5. Nakaz MOZ Ukraïni № 204 vid 29.12.1992 «Pro organizaciyu laboratornoï diagnostiki sifilisu v Ukraïni” (zi zminami, vnesenimi zgidno z Nakazom MOZ № 21 vid 3.01.97) [Order of the Ministry (9)

6. Kutasevich YaF, Kutovaya WV, Belokon ON, et al. Prakticheskiye aspekty serologicheskoy diagnostiki sifilisa na sovremennom etape [Practical aspects of the serological diagnosis of syphilis at the presents stage]. Dermatologíya ta venerologíya. 2020;1(87):39-43. DOl: 10.33743/2308066-2020-1-39-43 [in Russ.]

7. Kutova W, Bilokon OM, Nikitenko IM, et al. Rol netreponemnih laboratornih metodiv

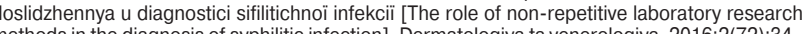
(1) infection]. Dermatologiya ta venerologiya. 2016:2(72):3439. [in Ukr.]

8. Rotanov SV. Meropriyatiya vneshnego kontrolya kachestva serologicheskikh issledovaniy, napravlennykh na serodiagnostiku sifilisa [Measures of external quality control of serological studies aimed at serodiagnosis of syphilis]. Vestnik dermatologii. 2008;4:9-16. [in Russ.]

9. Bondarenko GM, Unuchko SV, Nikitenko IN, et al. Sifilis: sovremennoe sostoyanie prob12. [in Russ.]

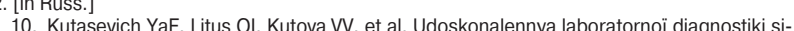
10. Kutasevich YaF, Litus OI, Kutova W, et al. Udoskonalennya laboratornoi diagnostiki siUkraine (guidelines]. Kyiv. 2019. 28 p. [in Ukr.]

11. Janier M, Hegyi V, Dupin $\mathrm{N}$, et al. European guideline on the management of syphilis.

J. Eur. Acad. Dermatol. Venereol. 2014;20:300-9. DOI: 10.1111/jdv.12734

12. Young H. Guidelines for serological testing for syphilis. Sex Transm. Infect. 2000;76:403-5. DOI: $10.1136 /$ sti.76.5.403

\section{ВОПРОСЫ ВНЕШНЕГО КОНТРОЛЯ КАЧЕСТВА ЛАБОРАТОРНЫХ ИССЛЕДОВАНИЙ СИФИЛИСА В ЛЕЧЕБНЫХ УЧРЕЖДЕНИЯХ УКРАИНЫ}

\author{
В.В. Кутовая, Я.Ф. Кутасевич, О.Н. Белоконь, Т.В. Дегтяр, И.Н. Никитенко, Ю. В. Щербакова
}

ГУ «Институт дерматологии и венерологии НАМН Украины»

\begin{abstract}
Резюме
Цель работы - выявление системных и случайных ошибок при постановке контролируемых методов и достижения сравнительных результатов, получаемых лабораториями, участвующими во внешнем контроле качества лабораторных исследова-
\end{abstract} ний на сифилис.

Материалы и методы. В мероприятиях проведения внешнего контроля качества серологической диагностики сифилиса приняли участие лаборатории трех уровней: клинико-диагностические лаборатории (КДЛ) лечебно-профилактических учреждений научно-исследовательских институтов НАМН Украины, серологические отделы в составе КДЛ дерматовенерологического профиля ОКВД, ГКВД.

Результаты. Оценено качество проведения серологических исследований на сифилис в 21 Кдл (серологических отделах) методами: РМП (реакция микропреципитации), РПР (реакция быстрых плазменных реагинов), ИХГ (иммунохроматография), РПГА (реакция пассивной гемагглютинации), РИФ абс (реакция иммунофлюоресценции с абсорбцией), ИФА (иммуноферментный анализ) в трех контрольных образцах сыворотки по формальным и существенным признакам. Наиболее значимые различия результатов были выявлены при исследовании контрольных образцов сыворотки с низким содержанием антител и не содержащих антитела к возбудителю сифилиса в нетрепонемном тесте РМП и трепонемном тесте РИФ

Выводы. Проведенные исследования показали высокую эффективность практического применения разработанной системы внешнего контроля качества лабораторных методов диагностики сифилиса.

Ключевые слова: сифилис, внешний контроль качества, серологические исследования. 


\section{КЛІНІЧНІ СПОСТЕРЕЖЕННЯ}

\section{ISSUES OF EXTERNAL QUALITY CONTROL OF LABORATORY STUDIES OF SYPHILIS IN MEDICAL INSTITUTIONS OF UKRAINE}

V.V. Kutova, Ya.F. Kutasevich, O.N. Belokon, T.V. Degtyar, I.N. Nikitenko, Yu.V. Shcherbakova SE «Institute of Dermatology and Venereology of NAMS of Ukraine»

\section{Abstract}

The objective of the work is to identify systemic and random errors in the formulation of controlled methods and to achieve comparative results obtained by laboratories participating in external quality control of laboratory tests for syphilis.

Materials and methods. Laboratories of three levels took part in the activities of external quality control of serological diagnostics of syphilis: clinical diagnostic laboratories (CDL) of medical institutions of scientific research institutes of the NAMS of Ukraine, serological departments as part of the CDL of the dermatovenerological profile of the RDVD, CDVD.

Results. The quality of serological tests for syphilis in $21 \mathrm{CDL}$ (serological departments) was assessed using the following methods: RMP, RPR, Rapid-test, TPHA, FTA-abs, ELISA in three control serum samples according to formal and essential characteristics. The most significant differences in the results were revealed in the study of control serum samples with a low content of antibodies and those without antibodies to the causative agent of syphilis in the non-treponemal RMP test and the treponemal FTA-abs test.

Conclusions. The conducted studies have shown the high efficiency of the practical application of the developed system of external quality control of laboratory methods for diagnosing syphilis.

Key words: syphilis, external quality control, serological tests.

\section{Відомості про авторів:}

Кутова Валентина Василівна - канд. мед. наук, ст. наук. співроб., зав. лабораторії серології ДУ «Інститут дерматології та венерології НАМН України»; е-mail: serolab_idv@i.ua

ORCID ID: https://orcid.org/0000-0002-0799-797X

Кутасевич Яніна Францівна - д-р мед. наук, професор, директор ДУ «Інститут дерматології та венерології НАМН України»; e-mail: idvnamnu@ukr.net

ORCID ID: https://orcid.org/0000-0001-8706-1487

Білоконь Ольга Миколаївна - мол. наук. співроб. лабораторії серології ДУ «Інститут дерматології та венерології НАМН України»; e-mail: serolab_idv@i.uа

ORCID ID: $h$ ttps://orcid.org/0000-0003-3281-8969

Дегтяр Тетяна Володимирівна - лікар-лаборант лабораторії серології ДУ «Інститут дерматології та венерології НАМН України»; e-mail: serolab_idv@i.ua

ORCID ID: $h$ ttp//orcid org/0000-0001-6618-1367

Нікітенко Інна Миколаївна - канд. мед. наук, ст. наук. співроб. відділу інфекцій, що передаються статевим шляхом, ДУ «Інститут дерматології та венерології НАМН України»; e-mail: nikitenko.inna.n@gmail.com

ORCID ID: $h$ ttps://orcid.org/0000-0001-8315-7625

Щербакова Юлія Валеріївна - д-р мед. наук, учений секретар дУ «/нститут дерматології та венерології НАМН України»; e-mail: iuliiashcherbakova@gmail.com

ORCID ID: https://orcid.org/0000-0002-3682-7451 